\title{
METHITURAL SODIUM FOR THE INDUCTION OF PAEDIATRIC ANAESTHESIA ${ }^{1}$
}

CODE SMITH, M.D., B.SC. (MED), F.R.C.P. $(\mathbb{C})^{2}$

NERAVAL ${ }^{3}$ BRAND OF METHITURAL SODIUM was administered to 225 paedriatic cases in a single injection for the induction of general anaesthesia. It was employed over a period of several months in all cases that would ordinarily receive a barbiturate intravenously. Patients receiving thiopental during the six months immediately preceding this investigation were used in making comparisons. The lack of randomization renders the data unsuitable for rigorous statistical evaluation.

\section{Age of Patients}

Methitural was used in all age groups whenever a vein was available for venapuncture or when a cut-down was running. Approximately 40 per cent of the patients were under five years of age; 20 per cent were under three years of age; and 10 per cent were under six months of age.

\section{Distribution of Cases by Age}

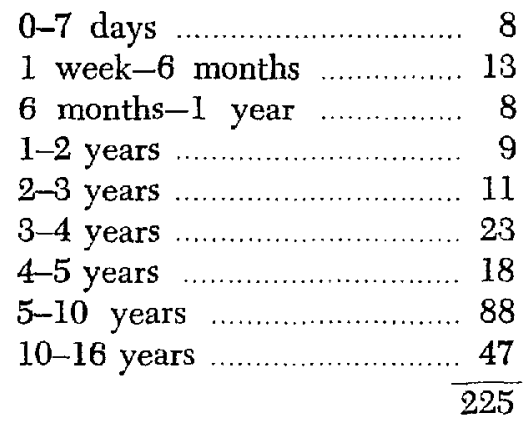

\section{Types of Surgery}

Methitural was employed before all types of operative surgery. All but two of the intrathoracic group were thoracotomies for congenital heart disease.

\begin{tabular}{|c|c|}
\hline Intracranial & 14 \\
\hline Surgery of head \& neck & 40 \\
\hline $\mathrm{T} \& \mathrm{~A}^{\prime} \mathrm{S}$ & \\
\hline Endoscopy & \\
\hline Intrathoracic & \\
\hline Intraabdominal & \\
\hline Cystoscopy ...... & \\
\hline Orthopaedics & \\
\hline $\begin{array}{l}\text { Superficial surgery } \\
\text { (excluding head \& neck). }\end{array}$ & \\
\hline Neurological investigation & \\
\hline Poftal venography .................... & \\
\hline
\end{tabular}

1 From the Department of Anaesthesia, Hospital for Sick Children, Toronto, Canada.

${ }^{2}$ Clinical Teacher, Department of Anaesthesia, University of Toronto.

'Donated for this study by the Schering Corp., through the courtesy of Dr. W. K. MacDonald. 


\section{Premedication}

Atropine alone was used in the majority of cases. No premedication was employed for those patients receiving ethyl chloride-ether sequence for adenotonsillectomy and endoscopy. Chlorpromazine and promethazine were used in four cases, and Padatal on two occasions.

\section{Combinations of Agents}

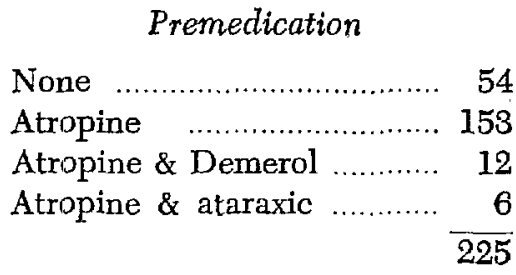

Methitural was used alone on one occasion. It was given as an immediately preanaesthetic hypnotid to 41 patients. The majority of patients received a relaxant, nitrous oxide-oxygen, with or without a volatile agent in addition to methitural.

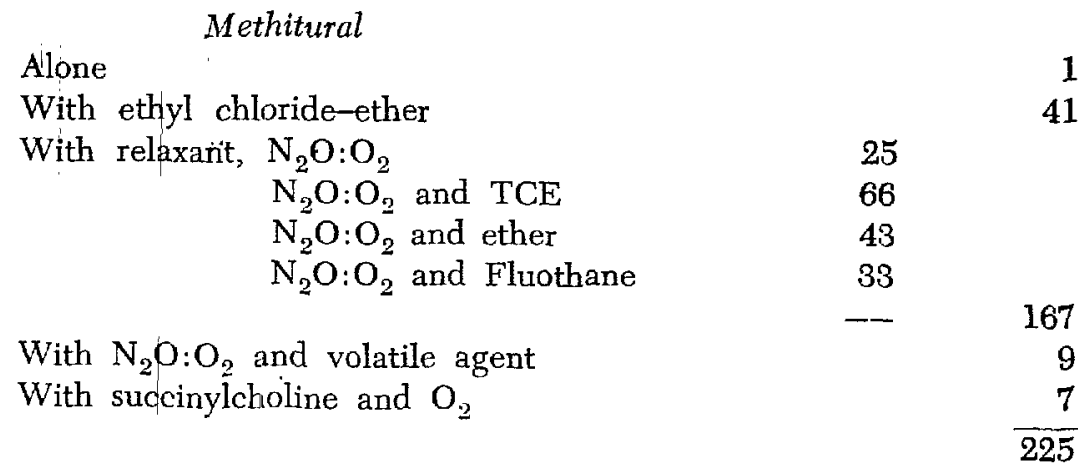

Properties of Methitural

The properties listed below have all been noted in; series of adult patients $(1,2,3,4,5,6,7)$. Compared with thiopental, they are: (1) a more prolonged period for induction; (2) a relative potency of about 70 per cent; (3) an increased incidence of coughing, hiccoughing and sneezing during induction; (4) pain at the site of injection when concentrations greater than 2.5 per cent are used; and (5) a shorter duration of action characterized by a faster, clearer recovery, free from "hangover".

\section{Clinical Observations}

Experience with children has confirmed the observations made on adults and noted above.

(1) Duration of induction. Loss of consciousness was noticeably slower than that to which we have become accustomed with thiopental. In smaller children this constituted a drawback. The prolonged presence of a needle in the arm resulted in a number of patients becoming restless. As a result, physical restraint was sometimes required, and this in turn increased the degree of apprehension. In order to avoid this disadvantage injections at a more rapid rate were attempted with results noted in section 3 below. 
(2) Potency. The average induction dose in this series was $5.3 \mathrm{mg}$./lb. as compared with $3.8 \mathrm{mg}$./lb. of thiopental used in similar cases. These figures give a relative potency of 72 per cent.

(3) Respiratory irritation. The effects of a slow induction with a 2.5 per cent solution were noted in section (1) above. Increasing the rate of injection resulted in a brief bout of coughing or sneezing in most cases. Coughing was also observed in eight of the ten patients that received a 5 per cent solution. In no case did coughing persist, nor did laryngeal or bronchial spasm occur. In two cases coughing was sufficiently forceful to dislodge the needle from the vein, necessitating a second puncture for the administration of a relaxant.

Hiccough was also encountered, lasting fifteen minutes in one case. On other occasions it was abolished either by the short period of apnea accompanying intubation or by a short period of hyperventilation.

Coughing, sneezing or hiccoughing occurred in a total of 23 cases, an incidence of 10 per cent. While these phenomena disturb the smoothness of the induction they do not constitute a serious contraindication to the use of methitural.

Spasm of the masseters was encountered once, and retching without vomiting on two occasions.

(4) Painful injection. Pain at the site of injection occurred in two patients. One patient receiving a 2.5 per cent solution had had multiple venapunctures in the same vein preoperatively. The other incident occurred during the injection of a 5 per cent solution.

(5) Duration of action and recovery. Statistically valid conclusions with respect to the duration of action of methitural relative to that of thiopental cannot be drawn from this study. The impression gained, however, was that methitural was relatively shorter in action. The evidence from the two largest and most nearly homogeneous groups in the series follows.

(a) The author's "routme" anaesthetic for cases not requiring abdominal relaxation has been a barbiturate induction with sufficient relaxant for either intubation or pharyngeal relaxation followed by nitrous oxide-oxygen-trichlorethylene by a non-rebreathing technique. The latter has been continued throughout operation unless tachypnoea has occurred. Ether, additional barbiturate, or Demerol has then been given as a supplement.

During the period of this study 123 patients premedicated with atropine alone were anaesthetized by the method outlined above for operations lasting between 60 and 90 minutes. Thiopental was used for 83 of the patients and methitural for

TABLE I

Patients given a Barbiturate Relaxant $\mathrm{N}_{2} \mathrm{O} \mathrm{O}_{2}$ TCE

\begin{tabular}{lcc}
\hline & Thiopental & Methitural \\
\hline Number of cases & 83 & 40 \\
Supplemented & 12 & 18 \\
Unsupplemented & 71 & 22 \\
Average dosage $(\mathrm{mg} / \mathrm{ab})$ & 338 & 53 \\
Relative potency $(\%)$ & 100 & 72 \\
\hline
\end{tabular}


40. Almost 50 per cent of the latter required some supplementation (Table I). In almost every case this was necessary during the first 20 minutes of anaesthesia. This result was in contrast to the small proportion of patients requiring supplementation following induction with thiopental. In the latter group the need almost never occurred during the first 45 minutes of anaesthesia.

In both the supplemented and unsupplemented groups there was a greater percentage of fully coherent patients five minutes following the termination of anaesthesia when methitural was used. The average recovery times in both groups were shorter when methitural was administered (Table II).

TABLE II

Recovery Period for Patients in Table I

\begin{tabular}{|c|c|c|c|c|}
\hline & \multicolumn{2}{|c|}{ Supplemented } & \multicolumn{2}{|c|}{ Unsupplemented } \\
\hline & Thiopental & Methitural & Thiopental & Methitural \\
\hline \multirow{3}{*}{$\begin{array}{l}\text { Number of cases } \\
\text { Percentage awake } \\
\text { within } 5 \text { minutes } \\
\text { Average recovery } \\
\text { time in minutes }\end{array}$} & 12 & 18 & 71 & 22 \\
\hline & 300 & 500 & 375 & 710 \\
\hline & 160 & 115 & 143 & 75 \\
\hline
\end{tabular}

(b) Table III reveals the average duration of unconsciousness of a group of patients undergoing superficial procedures of short duration. Methitural was given to 26 patients, and thilhpental to 25 . Both groups received nitrous oxideoxygen-trichlorethylene in addition to the barbiturate. Those receiving methitural had a shorter average period of unconsciousness.

TABLE III

\begin{tabular}{lcc}
\hline & Thiopental & Methitural \\
\hline Number of cases & 25 & 26 \\
Aierage cose (ming / lb) & 35 & 48 \\
Aierage curation of unc onscrousness in minutes & 333 & 252 \\
\hline
\end{tabular}

We believe that these results lend clinical support to the contention that methitural possesses a shorter duration of action than does thiopental.

A qualitative difference in the recovery from methitural anaesthesia has been claimed. The impression gained was that patients who received methitural had a more rapid return of full consciousness. Patients induced with thiopental frequently fall asleep after regaining consciousness and require rousing from time to time This situation was unusual in the patients induced with methitural. Several older children who had previously received thiopental volunteered that they felt more alert when methitural had been used.

\section{Methitural before Open Drop Anaesthesia}

Forty-one children were given just enough methitural to induce sleep before proceding with open drop ethyl chloride-ether anaesthesia. The average dose \pm S D. was $3.15 \pm 0.32 \mathrm{mg}$. $/ \mathrm{lb}$. All patients were light enough to react to 
the ethyl chloride induction by exhibiting withdrawal reflexes. Laryngospasm, coughing and breath-holding were noticeably absent. There was no respiratory depression at this level of dosage, and stage III plane 2 anaesthesia was rapidly. established. All patients regained their laryngeal and cough reflexes on the table. The recovery period was not prolonged and averaged 8.6 minutes. There was no memory of the inhalation induction.

\section{Methitural for Portal Venography}

During splenic puncture movement of the organ may result in laceration of the capsule and intraperitoneal haemorrhage. For this reason, apnoea of approximately 50 seconds duration is desirable for the recording of splenic pressures and the injection of radio-opaque dye for portal venography. The injection of $0.4 \mathrm{mg}$./lb. succinylcholine has been used to induce such periods of apnoea. Immediately preceding the administration of the relaxant unconsciousness has been produced in six patients with methitural in doses averaging $4.2 \mathrm{mg}$./lb. Five patients were fully conscious within five minutes of giving methitural. The sixth was fully conscious within eight minutes.

\section{Methitural in Hypothermia}

Patients induced with thiopental and subsequently cooled to $27-31^{\circ} \mathrm{C}$. have in many cases failed to regain consciousness until rewarmed to $34-35^{\circ} \mathrm{C}$. All cases subjected to hypothermia following induction with methitural have regained consciousness immediately following the termination of nitrous oxideoxygen anaesthesia, even at $29^{\circ} \mathrm{C}$.

Infants undergoing major surgery tend to become hypothermic. Several instances of prolonged recovery have occurred in the past when thiopental was used in this group. All infants induced with methitural have awakened immediately following the termination of anaesthesia at temperatures of $33-34^{\circ} \mathrm{C}$.

The hypothesis is that methitural, unlike thiopental, is almost completely eliminated during the cooling period, and that there is little residuum to be metabolized during rewarming. We feel that this is an advantage, since the conscious patient is able to move about, cry and expand his lungs fully, and thus assist in the rewarming phase.

\section{SUMMARY}

Experience with methitural sodium in 225 children ranging from one day to sixteen years of age indicates that this agent may be safely administered to all age groups and for all procedures in which other barbiturates are not contraindicated.

The annoyances of induction are the same as those reported for adults. coughing, sneezing, hiccoughing, retching, and pain at the site of injection. The prolonged induction period was a disadvantage in some children who were apprehensive and restless.

Our experience lends clinical support to the contention that methitural has a shorter duration of action than does thiopental. This property offers some 
advantage to those patients who may become hypothermic during operation, either deliberately or incidentally. It is of no advantage in normothermic cases lasting longer than thirty minutes, but is of value in shorter procedures, particularly for out-patients.

\section{REFERENCES}

1. O'Herlmy, D. B., Nishimura, N., Little, D. M., Jr., \& Tovell, R. M. The Clinical Usage of Neraval. Canad. Anaesth. Soc. J 3. 326-334 (1956).

2 Houde, J, Hunon, F, \& Jacques, A. Neraval (Methitural Sodium) (SCH 3132). Canad. Anaesth. Soc. J. 4: 43-46 (1957).

3 Fleming, S. A., \& Robinson, J G. Neraval Sodium: A Clnical Investigation. Canad. Anaesth. Soc. J. 4: 52-54 (1957).

4 Booñe, J D, MuÑoz, R., \& Dillon, J B. Neraval Sodium. A New Ultra-Short-Acting Thiobarbiturate: Prelimirary Clinical Investigations. Anesthiology 17. 284-287 (1956).

5. Ayd, F. J, Jr. Neraval. A New Anesthetic for Electroconvulsive Therapy. Progress Report to Schering Corporation, Bloomfield, N.J.

6. Riffin, I. M., \& BLock, M Induction of General Anesthesia with a New Ultra-Short Acting Agent, Methitural Sodium. Electrocardiographic Studies. To be published.

7 'Irwin, S, StagG, R. D, Dunbar, E., \& Govier, W. M A New Ultra-Short Acting Intravenous Anesthetıc. J Pharmacol \& Exper. Therap. 116. 32 (1956). 